\title{
DME as alternative fuel for compression ignition engines - a review
}

The ecological issues and the depletion of crude oil, has led the researchers to seeking for non-petroleum based alternative fuels, along with more advanced combustion technologies, and after-treatment systems. The use of clean alternative fuels is the one of the most perspective method that aiming at resolving of the said issues. One of the promising alternative fuels that can be used as a clean highefficiency compression ignition fuel with reduced of toxic emissions is dimethyl ether (DME). Moreover, it can be produced from various feedstocks such as natural gas, coal, biomass and others. This article describes the properties and the potential of DME application on the combustion and emission reduction characteristics of the compression ignition engines.

Key words: alternative fuels, dimethyl ether, DME, internal combustion engine, emission reduction

\section{Introduction}

Environmental pollution is the one of the most serious problems that the world is facing today, which is causing by the exhaust gases due to the burning of the fuels. This issue, leads to increasing the stringent regulations that are aimed to lowering the toxic emissions [6-8].

Internal combustion engines (ICE) have been widely used in the different sectors (i.e., transport, industry, agriculture etc.) due to their improved durability and efficiency. Unfortunately, the main energy source for piston engines nowadays is a crude oil, which stocks are significant, but not limitless. Continuously growing of the energy demand (Fig. 1, Fig. 2, Fig. 3) and number of cars (Fig. 4), leads to energy and political crisis related to the rapid depletion of crude oil. Studies indicate that the known reservoirs of the primary energy sources will sufficiently meet the worldwide demand for another 39 years for oil, 61 years for natural gas and 216 years for coal $[10,16]$.
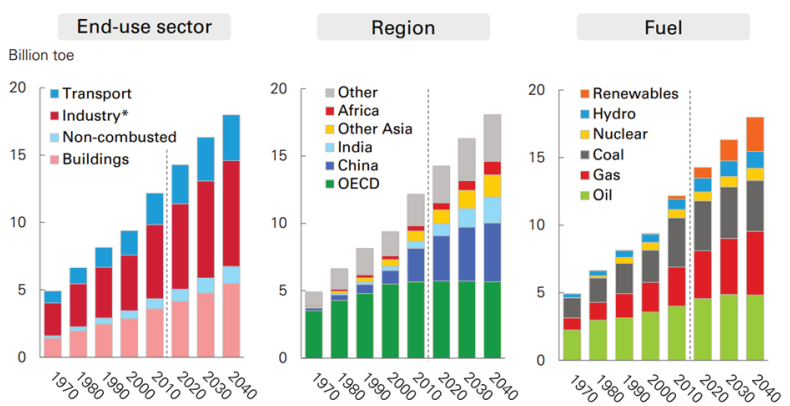

Fig. 1. Primary energy demand [3]
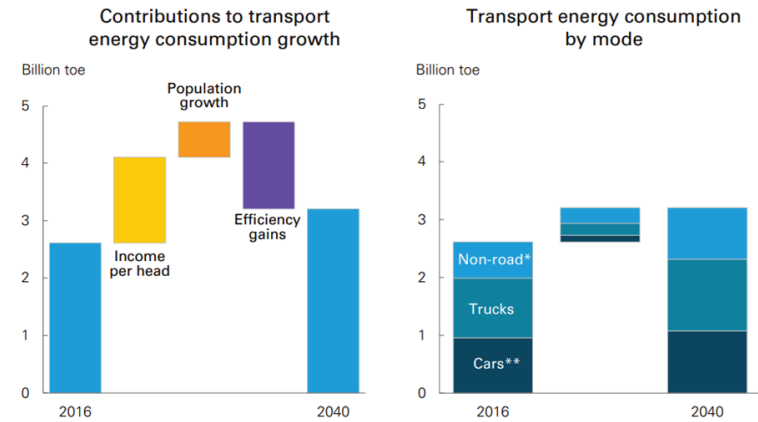

Fig. 2. Growth of fuels used in transport sector [3]: * - Aviation, Marine and Rail, **-Includes 2- and 3-wheelers

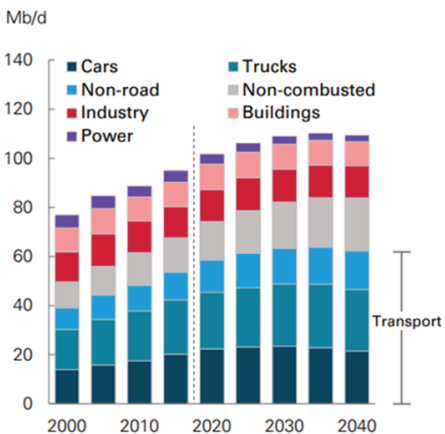

Fig. 3. Liquid fuels demand [3]. Cars include 2- and 3-wheelers, trucks include most SUVs in North America, non-road includes aviation, marine and rail

As presented on the Figure 3 the transport sector continues to dominate global oil demand.

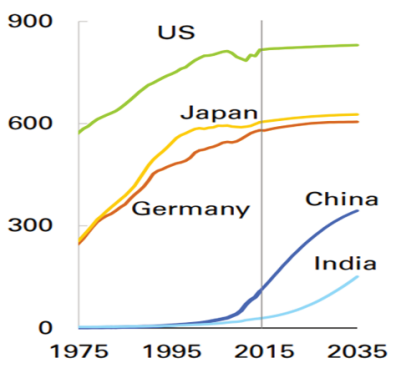

Fig. 4. The number of vehicles per 1000 inhabitants in individual regions in the world [14]

Transportation sector (i.e., cars, trucks, trains, ships, planes and other vehicles) is one of the main air pollution sources. According to different sources, road transport accounts from $23.5 \%$ [4] to $28 \%$ [9, 26] of all toxic emissions in the world. Air pollution carries significant risks for human health and the environment. The most harmful substances are nitrogen oxides $\left(\mathrm{NO}_{\mathrm{x}}\right)$, sulfur oxides $\left(\mathrm{SO}_{\mathrm{x}}\right)$, carbon dioxide $\left(\mathrm{CO}_{2}\right)$, hydrocarbons $(\mathrm{HC})$ and particulate matter (PM).

Stringent toxic emission regulations that are concerning on the reduction of the harmful compounds in exhaust gases, greenhouse gases as well as the reduction of fuel consumption are currently one of the most important factors affecting on the development directions of the: 
1. Internal combustion engines.

2. Exhaust after-treatment systems.

One of the most perspective methods that allows to solving the environmental pollution issues and the depletion of crude oil reserves, is the use of clean alternative fuels. Whatever fuel is to replace petroleum, it must address the following criteria:

1. There must be enough feedstock materials for the production on a large industrial scale.

2. Relatively low production and transportation costs.

3. Ensure high energy efficiency for the internal combustion engine.

4. Minimal or no negative impact of combustion products and pure fuel on the environment and human health.

5. If possible, use the already existing infrastructure without major changes of the:

- ICE fuel system,

- distribution and transportation of fuels to refill stations.

There are many alternative fuels that can potentially replace conventional petroleum oils including diesel and gasoline, such as biodiesel, light alcohol fuels, biomethane, natural gas, gas-to-liquid (GTL), coal-to-liquid (CTL), biomass-to-liquid (BTL), dimethyl ether (typically abbreviated as DME). Among these fuels the most promising alternative fuel for diesel engines that is suitable for all requirements is DME. The high cetane number over 55 (for diesel usually does not exceed 55), low boiling temperature, relatively low self-ignition temperature and good ecological properties turns out dimethyl ether to be a promising clean alternative fuel that can potentially replace diesel fuel.

The main objective of this paper is to discuss the combustion and emissions characteristics, and environmental effects of DME-fueled vehicles in order to highlight the potential of DME as a fuel in the compression ignition diesel engines and to share this useful information with researchers, engineers and anyone who interested in alternative fuels for diesel engines.

\section{Dimethyl ether}

DME (dimethyl ether) - it is the simplest ether compound with a formula of $\mathrm{CH}_{3}-\mathrm{O}-\mathrm{CH}_{3}$, with some important properties such, as high cetane number, high oxygen content (about $35 \%$ of mass), no direct $\mathrm{C}-\mathrm{C}$ bonds in the molecular structure (which produces considerably less pollutants like smoke and particulate matter (PM) than conventional fuels), low boiling point, low carbon to hydrogen ratio $(\mathrm{C} / \mathrm{H})$, has good solubility with diesel, environmentally benign and causes no negative health effects. To detect a leakage, DME does not require an odorant because it has a sweet ether-like odor. Under standard atmospheric conditions DME is a colorless gas, but it can easily condense to the liquid phase under the pressure at $0.5 \mathrm{MPa}$ at $25^{\circ} \mathrm{C}$. Liquefied DME has similar properties to those of liquefied petroleum gases (LPG). DME burns with a visible blue flame. The explosion characteristics presented in Table 1.

A tropospheric lifetime of dimethyl ether is 5.1 days $[23,25]$ therefore, DME does not affect on ozone depletion. The DME global warming potentials is 1.2 (20-year), 0.3 (100-year), and 0.1 (500-year). Based on the analysis and comparison presented in Table 2, it could be concluded that dimethyl ether is environmentally benign.
Thanks to its properties (Table 3) and large variety of raw materials (presented below), DME considered as a promising renewable energy source which can potentially replace conventional diesel fuel. These advantages led the researchers $[1,5,13,23-25,27,28]$ and many others, to provide investigations on the analysis of the conventional diesel engines fueled with pure DME or blended with diesel fuel.

Table 1. Explosion and hazard characteristics [23]

\begin{tabular}{|l|c|c|c|c|}
\hline \multicolumn{1}{|c|}{ Parameters } & DME & Diesel & Propane & Butane \\
\hline $\begin{array}{l}\text { Self-ignition tempera- } \\
\text { ture [K] }\end{array}$ & 508 & 523 & 743 & 638 \\
\hline $\begin{array}{l}\text { Lower explosion limit } \\
\text { [vol.\%] }\end{array}$ & $3.0-3.4$ & 0.6 & 2.1 & 1.9 \\
\hline $\begin{array}{l}\text { The upper limit of the } \\
\text { explosion [vol.\%] }\end{array}$ & $17-18.6$ & $6.5-7.5$ & 9.4 & 8.4 \\
\hline $\begin{array}{l}\text { Minimal ignition } \\
\text { energy [mJ] }\end{array}$ & 0.29 & - & 0.26 & 0.305 \\
\hline
\end{tabular}

Table 2. Global warming potentials [23, 25]

\begin{tabular}{|l|c|c|c|}
\hline \multirow{2}{*}{ Chemical compounds } & \multicolumn{3}{|c|}{ Time horizon (years) } \\
\cline { 2 - 4 } & 20 & 100 & 500 \\
\hline DME $\left(\mathrm{CH}_{3} \mathrm{OCH}_{3}\right)$ & 1.2 & 0.3 & 0.1 \\
\hline Carbon dioxide $\left(\mathrm{CO}_{2}\right)$ & 1 & 1 & 1 \\
\hline Methane $\left(\mathrm{CH}_{4}\right)$ & 56 & 21 & 6.5 \\
\hline Nitrous oxide $\left(\mathrm{N}_{2} \mathrm{O}\right)$ & 280 & 310 & 170 \\
\hline
\end{tabular}

\subsection{DME production}

Traditionally, DME is produced as a result of the conversion of various raw materials, such as natural gas, coal, biomass, plastics waste, municipal waste in two distinct ways (Fig. 5) [1, 2, 18, 21, 22]:

1. Indirect route by the dehydrogenation reaction of methanol (Fig. 6).

2. Direct route, in which DME is produced in a single stage by using a bi-functional catalyst directly from synthesis gas (Fig. 7).

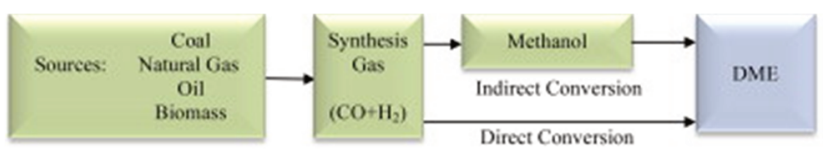

Fig. 5. DME production diagram [2]

\subsubsection{Indirect synthesis}

In this method DME is produced from syngas in a twostep process (Fig. 6):

- methanol produced from syngas,

- purification and dehydration of methanol.

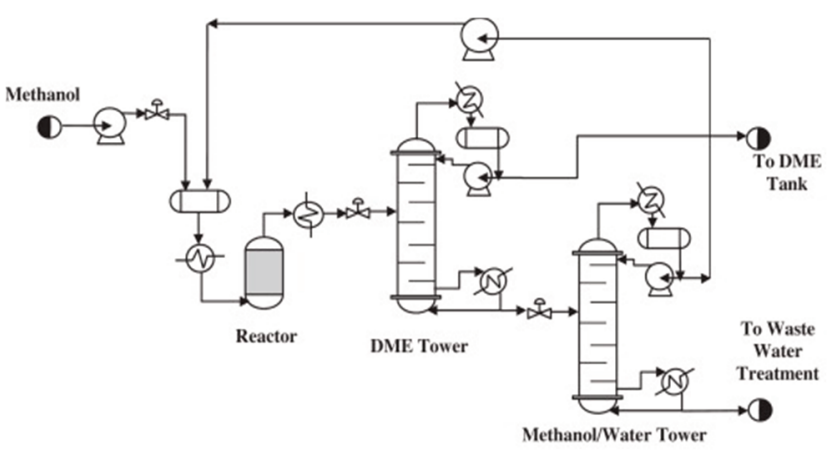

Fig. 6. A scheme of indirect synthesis process [2] 


\subsubsection{Direct synthesis}

Also, known as a single stage method, in which DME is produced directly from syngas (mixture of hydrogen and carbon monoxide $\left(\mathrm{CO}+\mathrm{H}_{2}\right)$ ) in a single reactor. The schematic of this process is shown in Fig. 7.

Single stage process is highly exothermic and, therefore, the temperature of the process should be controlled properly in order to avoid run-away [2].

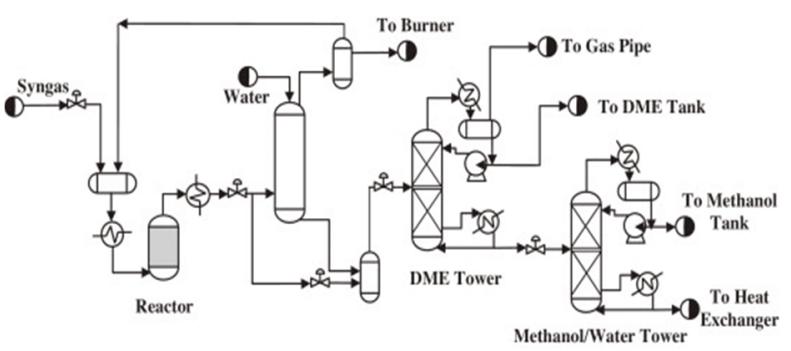

Fig. 7. A scheme of direct synthesis process [2]

\subsection{DME infrastructure}

The analysis and comparison of the vapor pressure diagram (Fig. 8), shows that the vapor pressure curve for DME falls between butane and propane curves. This means that, the storage, fuel handling, and transportation requirements are similar to those used for LPG and can be used for DME.

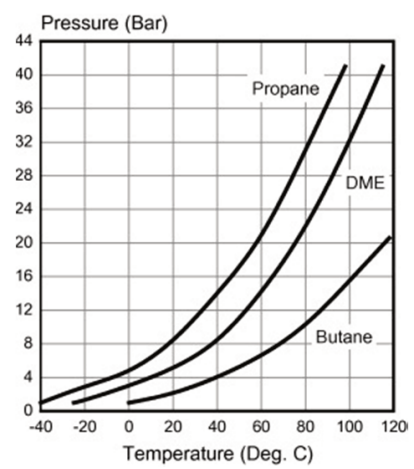

Fig. 8. The vapor pressure characteristics of different fuels [14, 23]

Since there are numerous LPG refilling stations, transitioning to dimethyl ether could be less costly than building a completely new infrastructure, of course the additional refueling stations would be built as the demand for dimethyl ether increases. Dimethyl ether can be offloaded and stored at the refilling station using the same methods and equipment as those used for LPG (Fig. 9). However, due to the different DME properties, LGP infrastructure must be redesigned (discussed in the following chapters).

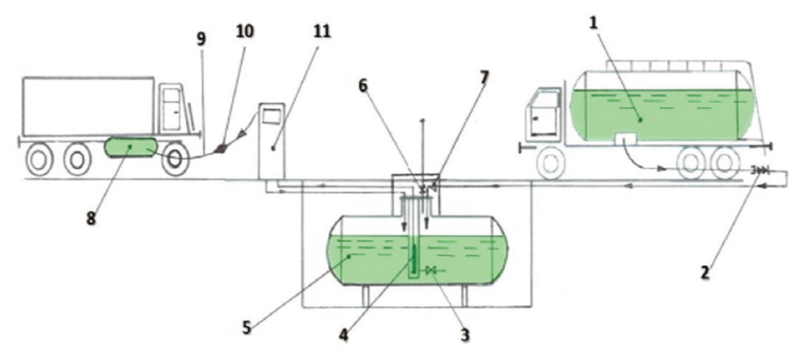

Fig. 9. DME distribution system to the refilling stations [12]

\subsection{Advantages and disadvantages}

The reasonableness of the DME use in the compression ignition engines can be determined by the detailed examining its advantages and disadvantages.

Advantages:

1. Due to a high cetane number DME has excellent ignition ability and short ignition delay.

2. Low boiling point leads to almost instantaneous evaporation of liquid DME after injection into the engine cylinder.

3. DME can be blended with various fuels such as, diesel, biodiesel, LPG and other.

4. Low carbon to hydrogen ratio than diesel fuel $(\mathrm{C} / \mathrm{H})$ results in a lesser amount of $\mathrm{CO}_{2}$ and greater amount of $\mathrm{H}_{2} \mathrm{O}$ generated following full combustion, which is the effect of the combustion of hydrogen [14].

5. High oxygen content together with the absence of any direct carbon-to-carbon $(\mathrm{C}-\mathrm{C})$ bonds leads to almost smoke-free combustion, and producing considerably less particulate matter (PM) than conventional diesel fuel.

6. Combustion noise from compression ignition engines is significantly lower when DME is used instead of diesel fuel, due to a slower pressure rise during the premixed burning stage.

7. DME can be applied to the compression ignition engine with minor modifications in the fuel supply system (discussed in the below sections of this paper).

8. Major benefit from this fuel is the big reduction of nitrogen oxides $\left(\mathrm{NO}_{\mathrm{x}}\right)$, carbon monoxide $(\mathrm{CO})$, hydrocarbon (HC) and particulate matter (PM) emissions, subject to the properly designed injection and combustion strategies [12, 13, 23].

According to the authors $[1,5,13,23-25,27]$ and others, the most challenging aspects of the DME use in the diesel engines are related to its physical properties and not to its combustion characteristics.

Disadvantages:

1. Because of the low boiling point DME is a gas in the standard atmospheric conditions, therefore it must be pressurized in a fuel system, stored in a pressurized tank, and handled in a liquid form under appropriate pressure.

2. Lower heating value requires a larger injected volume, longer injection period and advanced injection timing in order to deliver the same amount of energy to that provided by diesel fuel. To solve this problem, can be used injectors with a larger nozzle diameter. Moreover, to balance the energy content, the DME fuel tank must be correspondingly larger, which increase vehicle total weight.

3. Low viscosity causes leakage problems within the fuel supply system. To prevent this, issue it is necessary to appropriate sealing the elements in the fuel-injection systems.

4. Low lubricity leads to the surface wear problems of moving parts within the fuel-injection system. According to the authors $[12,23,24]$ the lubricity can be enhanced by addition of 500-2000 ppm of a lubricity additive such as, Lubrizol (1000 ppm), Hitec 560 (100 
ppm) and Infineum R655 (500 ppm). From the other hand, this issue can be solved by the adaptation of the materials of the bearing surfaces and plunger/barrel interfaces to the low lubricity of DME, however, this solution technically is very complex and expensive.

5. Dimethyl ether non-corrosive, but is an excellent solvent which can dissolve a number of elastomers most commonly used in the diesel engines and other plastic components [1]. To prevent seals quality deterioration after prolonged exposure of DME, it is necessary to carefully select appropriate sealing materials (such as polytetrafluoroethylene (PTFE)).

6. The high vapor pressure of DME means that cavitation can take place, which in turn impedes stable fuelinjection operation. To avoid cavitation the fuel supply pressure (the feed pressure from the storage tank to the fuel pump) must be between 1.2-3 $\mathrm{MPa}[1,12]$.

Table 3. Properties of alternative fuels compared to diesel fuel [10, 11, 13, 20, 23-25]

\begin{tabular}{|c|c|c|c|c|c|c|c|c|c|}
\hline Parametr & Diesel Fuel & DME & Butane & Propane & Methanol & Ethanol & Biomethane & $\begin{array}{l}\text { Biodiesel } \\
\text { FAME }\end{array}$ & GTL \\
\hline Chemical formula & $\begin{array}{c}\mathrm{C}_{\mathrm{n}} \mathrm{H}_{2 \mathrm{n}} \text { or } \mathrm{C}_{\mathrm{n}} \mathrm{H}_{2 \mathrm{n}+2} \\
(\mathrm{n}=13 \sim 17)\end{array}$ & $\mathrm{CH}_{3} \mathrm{OCH}_{3}$ & $\mathrm{C}_{4} \mathrm{H}_{10}$ & $\mathrm{C}_{3} \mathrm{H}_{8}$ & $\mathrm{CH}_{3} \mathrm{OH}$ & $\mathrm{C}_{2} \mathrm{H}_{5} \mathrm{OH}$ & $\mathrm{CH}_{4}$ & - & - \\
\hline $\begin{array}{l}\text { Molecular weight } \\
{[\mathrm{g} / \mathrm{mol}]}\end{array}$ & 170 & 46.07 & 58.13 & 44.11 & 32.042 & 46.07 & 16.04 & 296 & 259.6 \\
\hline $\begin{array}{l}\text { Liquid density at } 20^{\circ} \mathrm{C} \\
{\left[\mathrm{kg} / \mathrm{m}^{3}\right]}\end{array}$ & $800-840$ & 668 & 610 & 501 & 791.3 & 789.4 & 0.72 & 919.3 & 784.6 \\
\hline $\begin{array}{l}\text { Liquid viscosity at } 25^{\circ} \mathrm{C} \\
\text { [cSt] }\end{array}$ & $2-4$ & $0.12-0.15$ & 0.2 & 0.2 & 0.543 & 1.1 & 1.12 & 38 & 3.497 \\
\hline $\begin{array}{l}\text { Vapor pressure at } 25^{\circ} \mathrm{C} \\
\text { [bar] }\end{array}$ & - & 5.1 & 8.4 & 2.1 & - & - & $200-250$ & - & - \\
\hline $\begin{array}{l}\text { Boiling temperature } \\
{\left[{ }^{\circ} \mathrm{C}\right]}\end{array}$ & $125-400$ & -24.9 & -0.5 & -42.1 & 65 & 79 & -162 & $280-350$ & 72 \\
\hline $\begin{array}{l}\text { Self-ignition temperature } \\
{\left[{ }^{\circ} \mathrm{C}\right]}\end{array}$ & 254 & 235 & 365 & 470 & 385 & 363 & 470 & 261 & 254 \\
\hline Cetane number & $40-55$ & $55-60$ & 10 & 5 & 2 & 11 & 0 & $54-56$ & 79 \\
\hline $\begin{array}{l}\text { Lower heating value } \\
{[\mathrm{MJ} / \mathrm{kg}]}\end{array}$ & 36 & 28.43 & 45.74 & 46.36 & 20.08 & 26.83 & 44.4 & 34 & 43.65 \\
\hline Stoichiometric A/F [kg/kg] & 14.6 & 9.0 & 14.8 & 15.7 & 6.47 & 9.0 & 10.42 & 12.5 & 14.97 \\
\hline $\begin{array}{l}\text { Latent heat of evaporation } \\
{[\mathrm{kJ} / \mathrm{kg}]}\end{array}$ & 250 & 410 & 390 & 426 & 1162.64 & 918.42 & 511 & 254 & - \\
\hline $\begin{array}{l}\text { Content of carbon, oxygen } \\
\text { and hydrogen } \\
\text { [\% by mass] }\end{array}$ & $86 / 0 / 14$ & $52.2 / 34.8 / 13$ & $\begin{array}{c}82.8 / 0 / \\
17.2\end{array}$ & $75 / 0 / 25$ & $37.5 / 50 / 12.5$ & $\begin{array}{c}52.2 / \\
34.73 / \\
13.07 \\
\end{array}$ & $74 / 0 / 26$ & $\begin{array}{c}77 / 10.32 / \\
12.18\end{array}$ & $85 / 0 / 15$ \\
\hline $\begin{array}{l}\text { Sulfur content } \\
{[\mathrm{ppm}]}\end{array}$ & $\sim 250$ & 0 & 0,01 & 0,01 & 0 & 0 & 0 & $0.01 \max$ & $<0.05$ \\
\hline
\end{tabular}

\subsection{Application of dimethyl ether in diesel engine}

There are three main application modes of DME fuel in compression ignition engines:

1. Dual fuel combustion mode (fuel mixture ignited by the pilot diesel):

- DME injected into the inlet manifold. In this operation mode DME in gaseous form inducted into the intake air of the inlet manifold to form homogeneous mixtures and then ignited by the direct injected diesel in the cylinder. This mode is inexpensive and requires only minor modifications by adding a separate fuel tank, fuel lines and fuel injector. This method is roughly the same as LPG, demands the same kind of handling and storage considerations as for LPG. The schematic diagram of this mode is shown in Fig. 10.

- DME injected inside the cylinder in a liquid form. In this mode each fuel required a separate fuel supply sys- tem as presented in Fig. 11 or they can be injected via one injector.

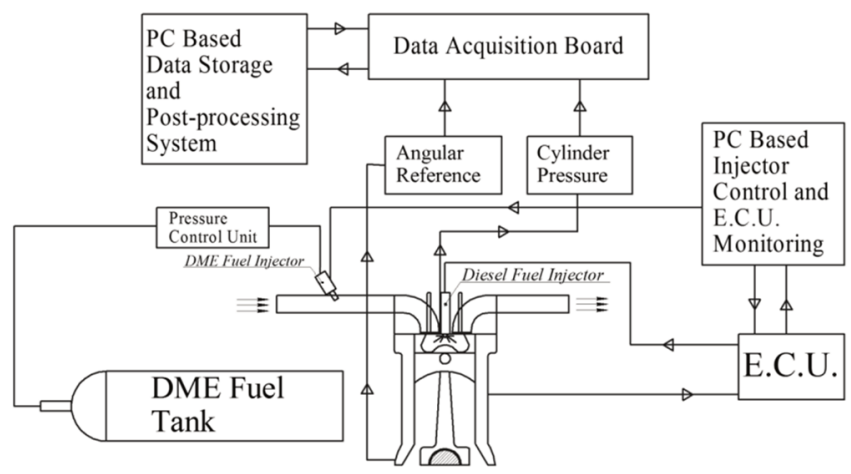

Fig. 10. Scheme of the ICE CI powered by gaseous DME 


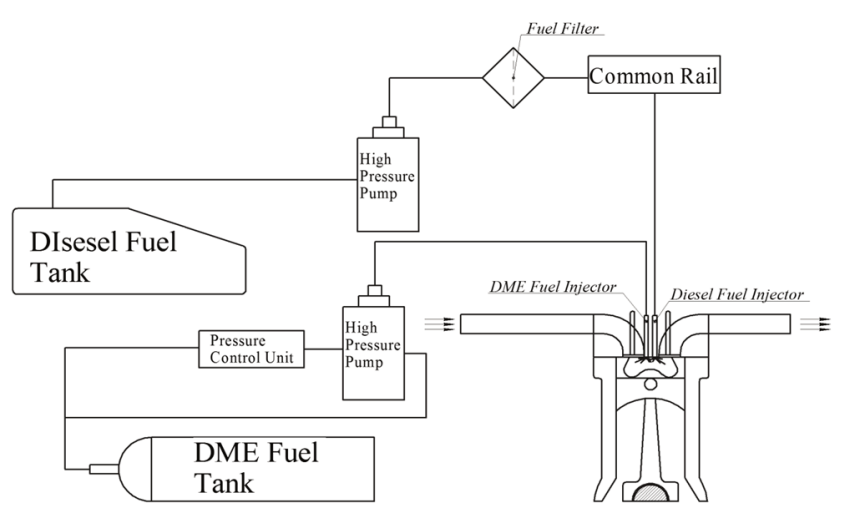

Fig. 11. Fuel system with two injectors

In dual fuel mode when alternative fuel runs out, then electronic control unit automatically switch engine to a reserve tank of diesel fuel.

2. Blended mode:

- One of the major benefits of DME is solubility with various fuels. In this point of view, according to the authors $[10,23]$ for example the blending of DME with propane improves the lower heating value of DME, the use of DME/biodiesel blend as engine fuel does not require any lubrication additive due to the high lubricity and viscosity of biodiesel. Fuel blended mode is a good inexpensive solution which does not require any modifications in the fuel supply system. Moreover, compared to the conventional diesel fuel, it is found that the blended fuel reduces toxic emissions in the exhaust gases $[5,10,23]$.

3. Single fuel mode:

- Due to, the high cetane number and great self-ignition abilities. DME can completely replace diesel fuel. Technically this solution is very complex and expensive, and requires major modifications in the fuel supply system.

\subsection{Combustion and emissions characteristics}

The evaluation on the combustion and emissions characteristics, include the calculated heat release rate and the cylinder pressure.

The authors [27] studied the operating parameters and emissions characteristics of diesel engine fueled with DME/Diesel blends (DM10 - 10\% DME and 90\% diesel, DM15 - 15\% DME, DM20 - 20\% DME). Fuel properties and the constitutions of three oxygenated blends are given in Table 4. According to authors [27] they used a commercial four-cylinder, water-cooled, naturally aspirated diesel engine 4113, made by Wu Xi diesel factory. No more modifications are made on the engine except the fuel pipe and fuel tank. The fuel pipe is changed into the copper one due to the causticity of DME to original rubber pipe. The diesel fuel tank is changed to LPG vessel to prevent DME from evaporating [27].

Table 4. Physical and chemical property of DME, diesel and DME/diesel blend [27]

\begin{tabular}{|c|c|c|c|c|c|}
\hline Properties & DME & Diesel & DM10 & DM15 & DM20 \\
\hline Liquid density, $\left[\mathrm{g} / \mathrm{cm}^{3}\right]$ & 0.668 & 0.84 & 0.823 & 0.814 & 0.803 \\
\hline Low calorific value, $[\mathrm{MJ} / \mathrm{kg}]$ & 28.43 & 42.5 & 41.1 & 40.4 & 39.7 \\
\hline Cetane number & $55-60$ & $40-55$ & $>40$ & cetane number & $<60$ \\
\hline Stoichiometric A/F, $[\mathrm{kg} / \mathrm{kg}]$ & 9.0 & 14.6 & 14.04 & 13.76 & 13.48 \\
\hline Latent heat of evaporation, $[\mathrm{kJ} / \mathrm{kg}]$ & 410 & 250 & - & - & - \\
\hline wt. $\%$ of carbon & 52.2 & 86 & 82.2 & 80.93 & 79.24 \\
\hline wt. $\%$ of oxygen & 34.8 & 0 & 3.48 & 5.22 & 6.96 \\
\hline wt. $\%$ of hydrogen & 13 & 14 & 13.9 & 13.85 & 13.8 \\
\hline
\end{tabular}

Figure 12 gives the comparison information of the power output of the engine fueled with four kinds of fuels at speed characteristics with a full load. It can be seen that the more DME percentage in blend is, the lower the power output is. The reasons are [27]:

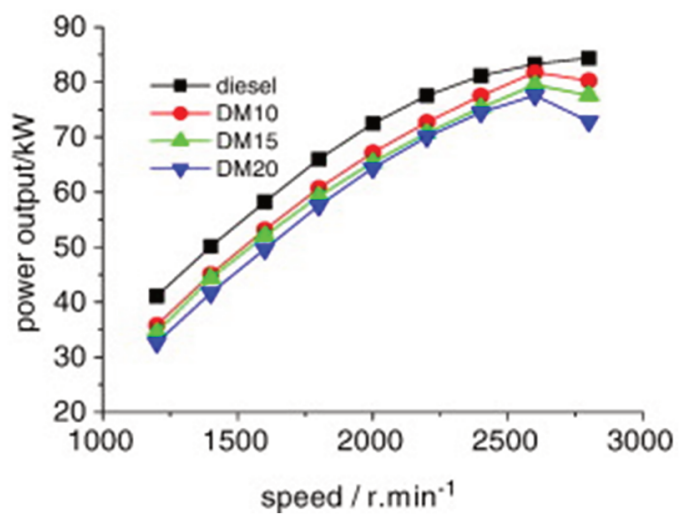

Fig. 12. The comparison of power outputs among various fuels [27]
1. The lower calorific value of blends compared to conventional diesel.

2. The smaller amount of fuel delivery resulted from lower density for blend fuels.

Increasing the amount of fuel delivered per cycle, can improved a power output parameters.

The heat release rate of various fuels is demonstrated in Fig. 13. It can be seen that the amount of heat release of diesel/DME blend fuels during the premixed combustion stage is smaller than that of diesel fuel. The smaller amount of heat release during the premixed combustion stage reduces the combustion pressure and temperature and leads to low $\mathrm{NO}_{\mathrm{x}}$ emission [27].

Figure 14 and Figure 15 show comparative values of various toxic compounds in the exhaust gasses. It can be seen that the use of DME/diesel blend as engine fuel can reduce smoke emissions significantly, especially at higher loads, in the same way $\mathrm{NO}_{\mathrm{x}}$ emissions are reduced somewhat in comparison with conventional diesel. The emissions of $\mathrm{HC}$ and $\mathrm{CO}$ are higher than those in diesel fuel. 
Authors [27] pointed to a need of the injection strategy optimization to reduce $\mathrm{HC}$ and $\mathrm{CO}$ emissions. Similar to authors [27], numerous studies [5, 10, 13, 23, 24] shows that $\mathrm{NO}_{\mathrm{x}}, \mathrm{PM}$ and smoke emissions are slightly lower than those of the diesel fuel operation, however, $\mathrm{HC}$ and $\mathrm{CO}$ emissions rise. According to the author's [10, 23], the HC and $\mathrm{CO}$ emissions could be reduced with an earlier injection period, which would promote the oxidation reaction of the $\mathrm{HC}$ and $\mathrm{CO}$ emissions. According the authors [13, 23, 24] $\mathrm{NO}_{\mathrm{x}}$ emissions reduces due to the larger temperature drop of the mixture due to heat absorption during DME vaporization causes by higher latent heat value of DME.

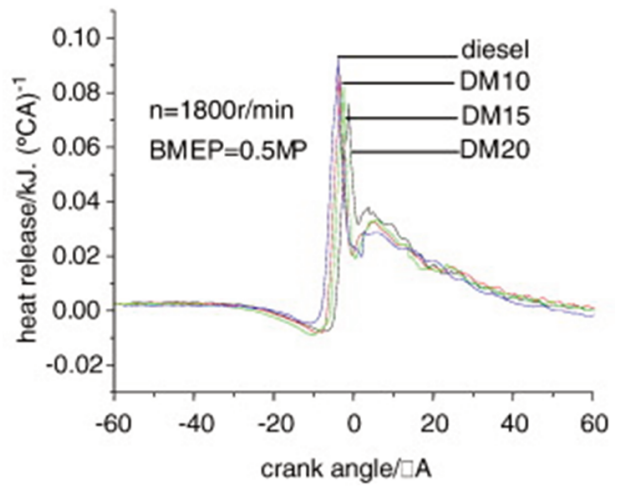

Fig. 13. The comparison of the heat release among various fuels [27]

On the other hand, numerous studies $[15,17,28]$, reported that $\mathrm{NO}_{\mathrm{x}}$ emissions are higher from DME combustion than diesel combustion, due to rapid ignition and a high combustion temperature.

However, high $\mathrm{NO}_{\mathrm{x}}$ emission from DME combustion can be easily reduced to a similar or lower level than that produced by diesel combustion by using a various methods such as exhaust gas recirculation (EGR) and optimization of the injection strategy, what is confirmed by many authors $[10,13,23,24]$.

Different results in the studies shows that, the emission characteristics of DME-fueled engines depends significantly on the engine specifications, fuel supply system, engine operating conditions including injection strategy (single or multiple injections, low or high injection pressure etc.).

Proper adaptation and optimization of the engine operating conditions including the injection strategy and operation algorithms of the diesel engine electronic control unit can helps to reach a state of clean emissions with current combustion technology (Fig. 16 and Fig. 17).

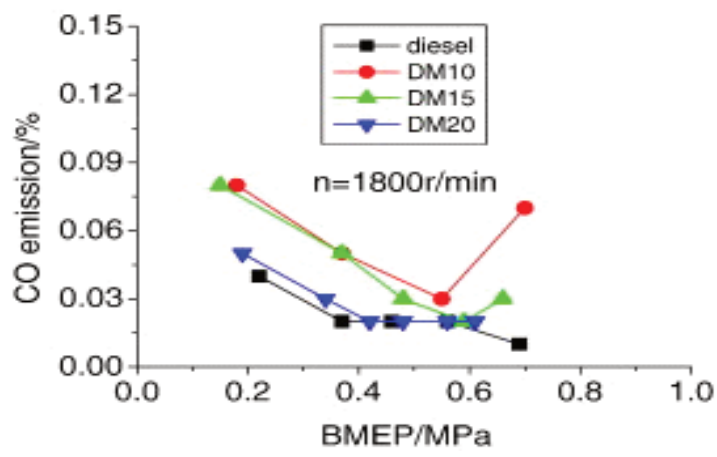

Fig. 14. The comparison of CO emissions [27]

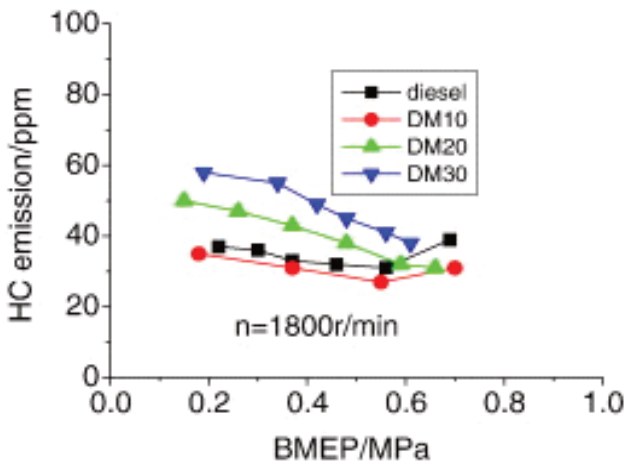

a) The comparison of $\mathrm{HC}$ emissions

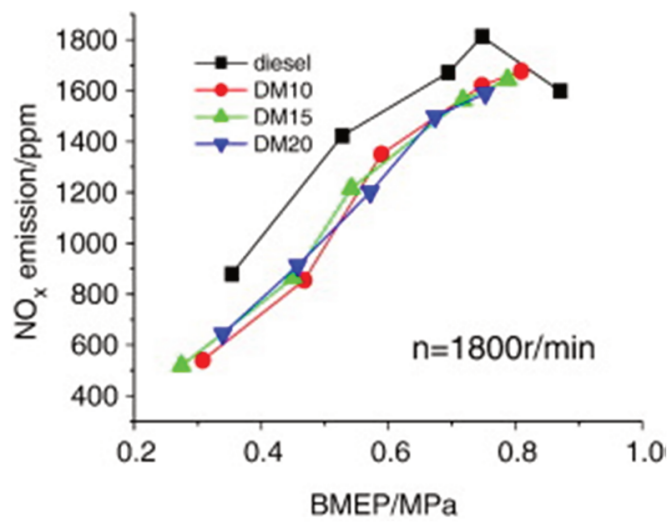

b) The comparison of $\mathrm{NO}_{\mathrm{x}}$ emissions

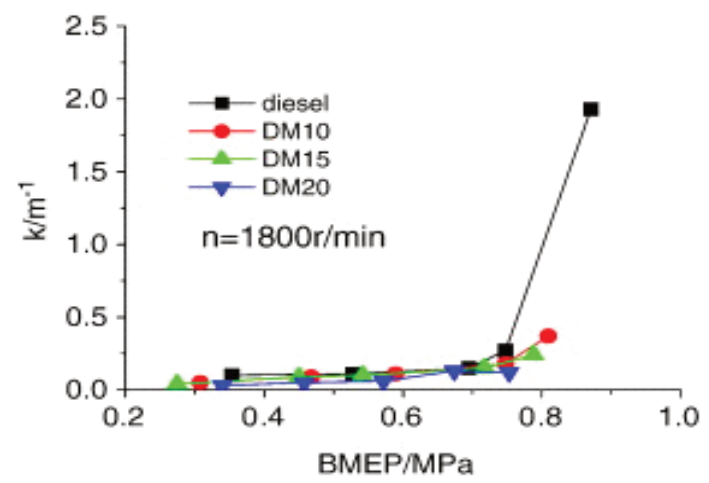

c) The comparison of smoke emission

Fig. 15. The comparison of harmful emissions among various fuels [27]

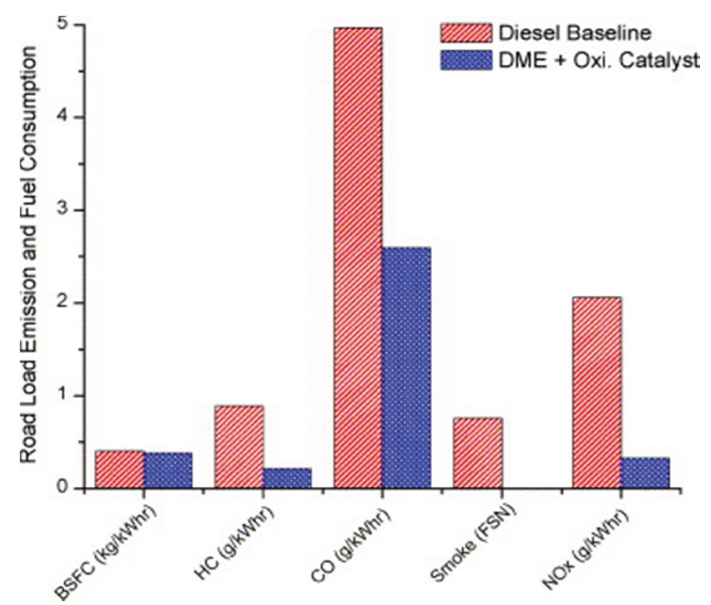

Fig. 16. The comparison of harmful emissions using diesel and neat DME [25] 


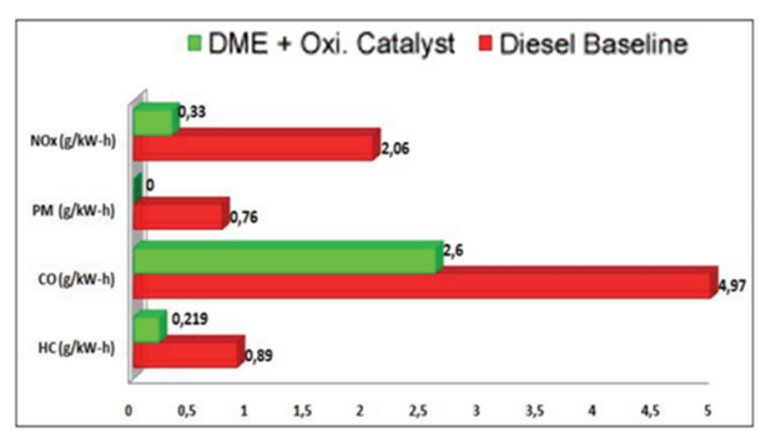

Fig. 17. The comparison of harmful emissions among the DME and diesel fuel [12]

\section{Cost of different fuel types}

One of the key features that determining the alternative fuels perspectives is price competition with conventional petroleum-based fuels. Simple and easily comparable information on the prices of different fuels could play an important role (Table 5) in enabling vehicle users to better evaluate the relative cost of different fuels available on the market [19], and as result in the consideration of alternative fuel as a substitute for petroleum fuels.

Table 5. Comparison of fuel prices [19]

\begin{tabular}{|l|c|c|c|c|}
\hline \multirow{2}{*}{ Type of fuel } & \multicolumn{2}{|c|}{ Energy content } & Fuel price & $\begin{array}{c}\text { Fuel price per 10 } \\
{[\mathrm{kWh}]}\end{array}$ \\
\cline { 2 - 3 }$\left[\begin{array}{c}{[\mathrm{MJ} / \mathrm{l}]} \\
{[\mathrm{kWh} / \mathrm{l}]}\end{array}\right.$ & & 1.730 \\
\hline Petrol & 32 & 8.88 & $1.536(€ / \mathrm{l})$ & 1.730 \\
\hline Diesel & 36 & 10 & $1.398(€ / \mathrm{l})$ & 1.398 \\
\hline Natural gas & 44.4 & 12.3 & $1.103(€ / \mathrm{kg})$ & 0.897 \\
\hline Biomethane & 44.4 & 12.3 & $1.103(€ / \mathrm{kg})$ & 0.897 \\
\hline LPG & 24 & 6.6 & $0.693(€ / 1)$ & 1.050 \\
\hline DME & 28.43 & 7.9 & $0.624(€ / 1)$ & 0.786 \\
\hline Biodiesel/B7 & 33 & 9.16 & $1.398(€ / \mathrm{l})$ & 1.526 \\
\hline
\end{tabular}

Each fuel has different calorific value so it is important to compare fuels with their energy content as kilowatt hour $(\mathrm{kWh})$ [19]. In this way, the differences between fuels in terms of energy content would be directly visible without the "detour" of a reference fuel [19]. A scaling in $10 \mathrm{kWh}$ would be more familiar to the consumer as $10 \mathrm{kWh}$ is equivalent to the energy content of a liter of diesel [19].

Currently it is quite difficult to determine the consumer cost of DME, and it is mainly depending on the raw material cost and production method. According to International DME Association, the DME consumer cost estimated at $75 \%-90 \%$ of LPG price.

\section{Conclusions}

Numerous investigations of DME-fueled engines have indicated that the DME offers excellent promise as an alternative fuel for compression ignition diesel engines that can address the pragmatic realization on depleting petroleum reserves and growing concerns on environmental pollution.

The prominent advantages of dimethyl ether as a fuel and energy carrier are high cetane number, superior atomization performance, high oxygen content, no direct $\mathrm{C}-\mathrm{C}$ bonds, low boiling point, low carbon to hydrogen ratio $(\mathrm{C} / \mathrm{H})$ and etc. Moreover, from the environmental benefits point of view, DME is better than diesel fuel, which has been also confirmed by numerous investigations. From technical point of view the DME fuel handling and storage system could be very similar to LPG systems very wellknown from automotive industry. In additional, DME may be produced from the renewable materials such as biomass or waste.

Overall, DME has been found to be a very promising alternative fuel for compression ignition engines that can potentially replace diesel fuel.

The further research by the authors of this paper, are the investigations of the DME fuel combustion in the Volkswagen AJM 1.9 TDI engine in dual fuel mode.

\section{Acknowledgements}

The authors wish to express their deep thanks to the Nouryon Company (Christian Neefestraat 2, 1077 WW Amsterdam) for the DME fuel and thanks to Elpigaz Company (ul. Perseusza 9, 80-299 Gdańsk) for the DME fuel supply system.

\section{Bibliography}

[1] ARCOUMANIS, C., BAE, C., CROOKES, R., KINOSHITA, E. The potential of di-methyl ether (DME) as an alternative fuel for compression-ignition engines: A review. Fuel. 2008, 87(7), 1014-1030.

[2] AZIZI, Z., REZAEIMANESH, M., TOHIDIAN, T., RAHIMPOUR, M.R. Dimethyl ether: a review of technologies and production challenges. Chem. Eng. Process. Process Intensif. 2014, 82, 150-172.

[3] BP Energy Economics. 2018 BP Energy Outlook 2018 BP Energy Outlook. 2018 BP Energy Outlook. 2018, 125.

[4] CHEN, X., WANG, Z., PAN. S., PAN, H. Improvement of engine performance and emissions by biomass oil filter in diesel engine. Fuel. 2019, 235, 603-609.

[5] CHEN, Y., SU, X. Emissions of automobiles fueled with alternative fuels based on engine technology: a review. $J$. Traffic Transp. Eng. 2018, 5(4), 318-334.

[6] CRIPPA, M., GRANIER, C. Forty years of improvements in European air quality: regional policy-industry interactions with global impacts. Atmos. Chem. Phys. 2016, 16(6), 3825-
3841.

[7] EC. Commission Regulation (EU) 2017/1151 of 1 June 2017 supplementing Regulation (EC) No 715/2007 of the European Parliament and of the Council on type-approval of motor vehicles with respect to emissions from light passenger and commercial vehicles Euro 5 a. 2017, 692, 1-643.

[8] BIELACZYC, P., WOODBURN, J. Current directions in LD powertrain technology in response to stringent exhaust emissions and fuel efficiency requirements. Combustion Engines. 2016, 166(3), 62-75. DOI:10.19206/CE-2016-341.

[9] EPA. Facts. Fast FastFacts acts U.S. Transportation Sect. Greenh. Gas Emiss. July 2018.

[10] GENG, P., CAO, E., TAN, Q., WEI, L. Effects of alternative fuels on the combustion characteristics and emission products from diesel engines: a review. Renew. Sustain. Energy Rev. 2017, 71, 523-534.

[11] GILL, S.S., TSOLAKIS, A., DEARN, K.D., RODRÍGUEZFERNÁNDEZ, J. Combustion characteristics and emissions of Fischer-Tropsch diesel fuels in IC engines. Prog. Energy 
Combust. Sci. 2011, 37(4), 503-523.

[12] GÓRSKI, W., JABŁONSSKA, M.M. Eter dimetylowy uniwersalne, ekologiczne paliwo XXI wieku. Inst. Naft. $i$ Gazu. 2012, 631-641.

[13] HOU, J., WEN, Z., JIANG, Z., QIAO, X. Study on combustion and emissions of a turbocharged compression ignition engine fueled with dimethyl ether and biodiesel blends. $J$. Energy Inst. 2014, 87(2), 102-113.

[14] IDZIOR, M., KARPIUK, W. Assessment of the potential of dimethyl ether as an alternative fuel for compression ignition engines. Combustion Engines. 2017, 169(2), 181-186.

[15] KAJITANI, S., CHEN, Z.L., KONNO, M., RHEE, K.T. Engine performance and exhaust characteristics of directinjection diesel engine operated with DME. SAE International, 1997.

[16] KESSEL, D.G. Global warming — facts, assessment, countermeasures. J. Pet. Sci. Eng. 2000, 26(1), 157-168.

[17] KIM, M.Y., YOON, S.H., RYU, B.W., LEE, C.S. Combustion and emission characteristics of DME as an alternative fuel for compression ignition engines with a high pressure injection system. Fuel. 2008, 87(12), 2779-2786.

[18] KISS, A.A., SUSZWALAK, D.J.-P.C. Innovative dimethyl ether synthesis in a reactive dividing-wall column. Comput. Chem. Eng. 2012, 38, 74-81.

[19] KOLB, O., SIEGEMUND, S. Study on the Implementation of Article 7(3) of the "Directive on the Deployment of Alternative Fuels Infrastructure" - Fuel Price Comparison Study on the Implementation of Article 7(3). Directive on the Deployment of Alternative Fuels Infrastr. 2017, 7(3).

[20] LAPUERTA, M., ARMAS, O., HERNÁNDEZ, J.J., TSOLA-

Denys Stepanenko, MEng. - Faculty of Mechanical Engineering, Gdansk University of Technology.

e-mail:denstepa@student.pg.edu.pl
KIS, A. Potential for reducing emissions in a diesel engine by fuelling with conventional biodiesel and Fischer-Tropsch diesel. Fuel. 2010, 89(10), 3106-3113.

[21] LEONZIO, G. State of art and perspectives about the production of methanol, dimethyl ether and syngas by carbon dioxide hydrogenation. J. CO2 Util. 2018, 27, 326-354.

[22] LUU, M.T., MILANI, D., WAKE, M., ABBAS, A. Analysis of di-methyl ether production routes: process performance evaluations at various syngas compositions. Chem. Eng. Sci. 2016, 149, 143-155.

[23] PARK, S.H., LEE, C.S. Applicability of dimethyl ether (DME) in a compression ignition engine as an alternative fuel. Energy Convers. Manag. 2014, 86, 848-863.

[24] PARK, S.H., LEE, C.S. Combustion performance and emission reduction characteristics of automotive DME engine system. Prog. Energy Combust. Sci. 2013, 39(1), 147-168.

[25] SEMELSBERGER, T.A., BORUP, R.L., GREENE, H.L. Dimethyl ether (DME) as an alternative fuel. J. Power Sources. 2006, 156(2), 497-511.

[26] U.S. EPA. Inventory of U.S. Greenhouse Gas Emissions and Sinks (1990-2016). United Stats Environ. Prot. Agency, 2018.

[27] YING, W., GENBAO, L., WEI, Z., LONGBAO, Z. Study on the application of DME/diesel blends in a diesel engine. Fuel Process. Technol. 2008, 89(12), 1272-1280.

[28] YOUN, I.M., PARK, S.H., ROH, H.G., LEE, C.S. Investigation on the fuel spray and emission reduction characteristics for dimethyl ether (DME) fueled multi-cylinder diesel engine with common-rail injection system. Fuel Process. Technol. 2011, 92(7), 1280-1287.

Zbigniew Kneba, DSc., DEng. - Faculty of Mechanical Engineering, Gdansk University of Technology. e-mail: zkneba@pg.edu.pl
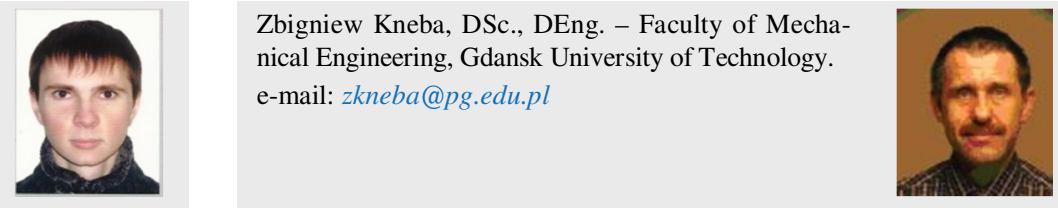